\title{
An altered expression of genes involved in the regulation of ion channels in atrial myocytes is correlated with the risk of atrial fibrillation in patients with heart failure
}

\author{
MEI GAO, JIANGRONG WANG, ZHONGSU WANG, YONG ZHANG, \\ HUI SUN, XINXING XIE and YINGLONG HOU \\ Department of Cardiology, Shandong Provincial Qianfoshan Hospital, Shandong University, Jinan, P.R. China
}

Received December 3, 2012; Accepted January 22, 2013

DOI: $10.3892 /$ etm.2013.949

\begin{abstract}
The aim of this study was to investigate the correlation between the altered expression of genes involved in the regulation of ion channels in atrial myocytes and the risk of atrial fibrillation (AF) in patients with heart failure (HF). Right atrial appendages were obtained from $18 \mathrm{HF}$ patients and 18 patients with normal cardiac functions who had undergone surgery. The mRNA expression levels of Kv4.3 $\alpha$, KvLQT1, Kv1.5, L-Ca $\alpha_{1 \mathrm{c}}$ and NCX were measured by reverse transcription-PCR (RT-PCR). Protein expression levels were also detected by western blotting. In comparison with the control group exhibiting normal cardiac functions, the mRNA and protein expression levels of Kv4.3 $\alpha$, KvLQT1 and L-Ca $\alpha_{1 \mathrm{c}}$ were significantly reduced in HF patients. By contrast, the mRNA and protein expression levels of NCX were significantly increased in HF patients compared with the control group $(\mathrm{P}<0.01)$. The mRNA expression levels of Kv1.5 were not evidently altered. We demonstrated that increased levels of Kv4.3 $\alpha$, KvLQT1 and L-Ca $\alpha_{1 \mathrm{c}}$ and decreased levels of NCX are correlated with the risk of AF in HF patients. Changes in the gene expression of ion channel-related proteins may therefore be used as biological markers of AF occurring in $\mathrm{HF}$ patients in future studies.
\end{abstract}

\section{Introduction}

Congestive heart failure (CHF) is a powerful, independent predictor of atrial fibrillation (AF), with $\mathrm{CHF}$ patients exhibiting a 6-fold increase in the relative risk of developing AF (1). Research on the abnormal ventricular electrophysiological properties associated with heart failure (HF) have been

Correspondence to: Professor Yinglong Hou, Department of Cardiology, Shandong Provincial Qianfoshan Hospital, Shandong University, No. 16766, Jingshi Road, Jinan 250014, P.R. China E-mail: yinglonghou@yahoo.cn

Key words: heart failure, atrial fibrillation, ion channel, gene expression performed, however, the mechanism of electrical remodeling in atrial muscle presently remains unknown. Furthermore, previous studies were mainly focused on atrial electrical remodeling after the development of AF (2-9), with only a few studies reporting on patients with organic heart disease in sinus rhythm.

Li et al (10) studied a dog model with CHF induced by ventricular pacing at 220-240 bpm for 5 weeks and discovered that $\mathrm{CHF}$ significantly reduces the density of the L-type $\mathrm{Ca}^{2+}$ current $\left(\mathrm{I}_{\mathrm{Ca} 2+}\right)$, the sensitive transient outward $\mathrm{K}^{+}$current $\left(\mathrm{I}_{\mathrm{to1}}\right)$ and the slow delayed rectifier $\mathrm{K}^{+}$current $\left(\mathrm{I}_{\mathrm{Ks}}\right)$ in atrial myocytes without altering their voltage dependencies or kinetics. The inward rectifier $\mathrm{K}^{+}$current $\left(\mathrm{I}_{\mathrm{ki}}\right)$, the ultra rapid rectifier $\mathrm{K}^{+}$ current $\left(\mathrm{I}_{\mathrm{kur}}\right)$ and the rapid delayed rectifier $\mathrm{K}^{+}$current $\left(\mathrm{I}_{\mathrm{kr}}\right)$ were not altered by $\mathrm{CHF}$, while the transient inward $\mathrm{Na}^{+} / \mathrm{Ca}^{2+}$ exchanger $\left(\mathrm{I}_{\mathrm{NCX}}\right)$ current was increased. In addition, Cha et al $(11,12)$ discovered that CHF downregulates $\mathrm{I}_{\mathrm{to} 1}, \mathrm{I}_{\mathrm{Ks}}$ and $\mathrm{I}_{\mathrm{Ca} 2+}$, and upregulates $\mathrm{I}_{\mathrm{NCX}}$ without altering $\mathrm{I}_{\mathrm{ki}}$. Clearly, these studies mainly focused on the alteration of ion currents rather than the gene expression of ion channels in atrial myocytes. Due to technical restrictions, ionic currents in atrial myocytes were not able to be tested.

In this study, we have identified possible alterations in atrial cellular ion currents and the molecular mechanisms involved in HF. The underlying mechanisms predisposing HF patients to AF have also been investigated. We demonstrated that when compared with the normal cardiac function group, the mRNA expression levels of Kv4.3 $\alpha$, KvLQT1 and L-Ca $\alpha_{1 \mathrm{c}}$ were significantly reduced in patients with HF. The mRNA expression levels of Kv1.5 were not evidently altered, while mRNA expression levels of NCX increased significantly. These changes in gene expression were in accordance with alterations in ion currents demonstrated in the previous studies mentioned above (10-12). Our results indicate that alterations in the gene expression of ion channels may explain the molecular basis of altered ion currents in the atrial myocytes of patients with HF.

\section{Materials and methods}

Patients. Thirty-six consecutive patients with sinus rhythm (15 males and 21 females, aged 29-62 years old with a mean age of $44.7 \pm 6.94$ years) undergoing coronary artery bypass 
Table I. Primers used in this study.

\begin{tabular}{|c|c|c|}
\hline Gene & Primer sequence & Fragment (bp) \\
\hline GAPDH & $\begin{array}{l}\text { F 5'-CCCATCACCATCTTCAGGAGCG-3' } \\
\text { R 5'-GGCAGGGATGATGTTCTGGAGAGCC-3' }\end{array}$ & 411 \\
\hline $\mathrm{Kv} 4.3 \alpha$ & $\begin{array}{l}\text { F 5'-CAGCAAGTTCACAAGCATCC-3' } \\
\text { R 5'-AGCTGGCAGGTTAGAATTGG-3' }\end{array}$ & 649 \\
\hline KvLQT1 & $\begin{array}{l}\text { F 5'-AGCAGAAGCAGAGGCAGAAG-3' } \\
\text { R 5'-GACGGAGATGAACAGTGAGG-3' }\end{array}$ & 370 \\
\hline Kv1.5 & $\begin{array}{l}\text { F 5'-AACGAGTCCCAGCGCCAGGT-3' } \\
\text { R 5'-AGGCGGATGACTCGGAGGAT-3' }\end{array}$ & 326 \\
\hline $\mathrm{L}-\mathrm{Ca} \alpha_{1 \mathrm{c}}$ & $\begin{array}{l}\text { F 5'-CTGGACAAGAACCAGCGACAGTGCG-3' } \\
\text { R 5'-ATCACGATCAGGAGGGCCACATAG G-3' }\end{array}$ & 563 \\
\hline $\mathrm{NCX}$ & $\begin{array}{l}\text { F 5'-CTACCAAGTCCTAAGTCAGCAGC-3' } \\
\text { R 5'-GATCCGAGGCAAGCAAGTGTAGA-3' }\end{array}$ & 519 \\
\hline
\end{tabular}

surgery at the Qianfoshan Hospital of Shandong University and the Jinan Central Hospital Affiliated to Shandong University (China) were enrolled. Among these, 18 cases presented with coronary heart disease, 5 with dilated myocardial disease, 6 with rheumatic heart disease and 7 with congenital heart disease. Patients with an eject fraction $(\mathrm{EF})<0.4$ were defined as the HF group $(33.67 \pm 3.68 \%)$ while those with $\mathrm{EF}>0.4$ were defined as the normal cardiac function group (60.28 $4.98 \%)$. The study cohort was extremely homogeneous for age, gender and overall etiology constitution. The study was approved by the ethics committee of Shandong Provincial Qianfoshan Hospital, Jinan, China. Written informed patient consent was obtained from the patient's family

Reverse transcription-PCR (RT-PCR). The internal standard gene used was glyceraldehyde-3-phosphate dehydrogenase (3-GAPDH) and the target genes included the channel determinant genes of $\mathrm{I}_{\mathrm{tol}}(\mathrm{Kv} 4.3 \alpha), \mathrm{I}_{\mathrm{ks}}(\mathrm{KvLQT1}), \mathrm{I}_{\mathrm{kur}}(\mathrm{Kv} 1.5), \mathrm{I}_{\mathrm{Ca} 2+}$ $\left(\mathrm{L}-\mathrm{Ca} \alpha_{1 \mathrm{c}}\right)$ and $\mathrm{I}_{\mathrm{NCX}}(\mathrm{NCX})$. Trizol ${ }^{\circledR}$ Reagent was purchased from Gibco BRL (Shanghai BioAsia Biotechnology Co. Ltd., Shanghai, China). The RNA PCR kit (AMV) Ver. 3.0 was purchased from Takara Bio, Inc. (Dalian, China). The primer sequences were provided by Shanghai BioAsia Biotechnology Co., Ltd. (Table I).

Open-chest cardiac surgery was performed and 50-100 mg samples of right atrial appendages were rapidly collected with sterilized Eppendorf tubes. The sample was frozen at $-80^{\circ} \mathrm{C}$ immediately following the addition of $0.5 \mathrm{ml}$ TRIzol. The total RNA was extracted using the TRIzol method. The extraction was dissolved by adding $40 \mu \mathrm{l}$ DEPC and then measured by a spectrophotometer, with the optical density (OD) $260 / \mathrm{OD} 280>1.8$ and thereafter stored at $-20^{\circ} \mathrm{C}$ for detection. RT-PCR technology was applied for reverse transcription and cDNA fragment amplification. The first-strand cDNA was synthesized using AMV reverse transcriptase. Total RNA was reverse transcribed in a final volume of $10 \mu \mathrm{l}$, containing the following: $2 \mu \mathrm{l} \mathrm{MgCl}_{2}(25 \mathrm{mM}) ; 1 \mu \mathrm{l}$ 10X RT buffer; $3.75 \mu \mathrm{l}$ RNase free $\mathrm{dH}_{2} \mathrm{O} ; 1 \mu \mathrm{l}$ dNTP mixture (10 mM); $0.25 \mu \mathrm{l}$ RNase inhibitor; $0.5 \mu \mathrm{l}$ AMV reverse transcriptase; $0.5 \mu \mathrm{l}$ oligo dT-adaptor primer; $1 \mu \mathrm{l}$ RNA. The reverse transcription was then conducted as follows: the reac- tion mixture was incubated at $30^{\circ} \mathrm{C}$ for $10 \mathrm{~min}$, annealed at $42^{\circ} \mathrm{C}$ for $30 \mathrm{~min}$, followed by incubation at $99^{\circ} \mathrm{C}$ for $5 \mathrm{~min}$ and $5^{\circ} \mathrm{C}$ for $5 \mathrm{~min}$. Following denaturation at $94^{\circ} \mathrm{C}$ for $2 \mathrm{~min}$, the samples were subjected to 30 cycles of denaturation at $94^{\circ} \mathrm{C}$ for $30 \mathrm{sec}$, annealing for $30 \mathrm{sec}$ and extension at $72^{\circ} \mathrm{C}$ for $50 \mathrm{sec}$. Then, 35 cycle PCR amplification was used with a 5-min extension time (reaction solution 2). The $10 \mu \mathrm{l}$ of amplified product was electrophoresed in $1.5 \%$ agarose gel containing ethidium bromide, examined and photographed under a UV transilluminator. The intensity of each band was quantified using image analysis software (TINA version 2.10, Raytest, Straubenhardt, Germany) and the expression levels were calculated by measuring the OD of the target gene and normalized to that of the amplified GAPDH.

Western blot analysis. All relevant proteins were harvested from tissue, separated by $10 \%$ SDS/PAGE and then subjected to immunoblot analyses. The primary antibodies against $\mathrm{Kv} 4.3 \alpha, \mathrm{KvLQT1}, \mathrm{Kv1.5}, \mathrm{L}-\mathrm{Ca} \alpha_{1 \mathrm{c}}$, NCX and actin were purchased from Santa Cruz Biotechnology, Inc. (Santa Cruz, CA, USA; anti-Kv4.3 $\alpha$, cat\# sc-11686, 1:200; anti-KvLQT1, cat\# sc-365186, 1:200; anti-Kv1.5, cat\# sc-377110, 1:200; antiL-Ca $\alpha_{1 c}$, cat\# sc-166069, 1:200; anti-NCX, cat\# sc-32881, 1:200; anti-actin, cat\# sc-130301, 1:10,000). Secondary antibodies used in this study were donkey anti-goat IgG-HRP (cat\# sc-2020, 1:5,000, Santa Cruz Biotechnology, Inc.), goat anti-rabbit IgG-HRP (cat\# sc-2004, 1:5,000, Santa Cruz Biotechnology, Inc.) and goat anti-mouse IgG-HRP (cat\# sc-2005, 1:10,000, Santa Cruz Biotechnology, Inc.). Bound antibodies were detected using the ECL system (Pierce Biotechnology, Inc., Rockford, IL, USA). The immunoblot experiments were repeated at least 3 times. The mean normalized OD of detected Kv4.3 $\alpha$, KvLQT1, Kv1.5, L-Ca $\alpha_{1 \mathrm{c}}$ or NCX protein bands relative to the OD of the actin band from the same individual was calculated, respectively.

Statistical analysis. Concise Statistics 2000 was used to perform the statistical analyses. All numerical values are expressed as mean $\pm \mathrm{SD}$. The t-test was performed for comparison of the experimental group and the control group. $\mathrm{P}<0.05$ was used to indicate a statistically significant result. 
Table II. mRNA expression of multiple ion channels in the right atria of patients in the normal cardiac function group, compared with the HF group (mean $\pm \mathrm{SD})$.

\begin{tabular}{lcccccc}
\hline Group & No. of patients & Kv4.3 $\alpha /$ GAPDH & KvLQT1/GAPDH & Kv1.5/GAPDH & L-Ca $\alpha_{1 c} /$ GAPDH & NCX/GAPDH \\
\hline Normal & 18 & $0.83 \pm 0.07$ & $0.56 \pm 0.04$ & $0.34 \pm 0.07$ & $0.42 \pm 0.09$ & $0.19 \pm 0.05$ \\
HF & 18 & $0.45 \pm 0.09^{\mathrm{a}}$ & $0.36 \pm 0.06^{\mathrm{a}}$ & $0.30 \pm 0.05$ & $0.25 \pm 0.06^{\mathrm{a}}$ & $0.31 \pm 0.07^{\mathrm{a}}$ \\
\hline
\end{tabular}

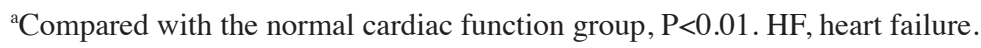

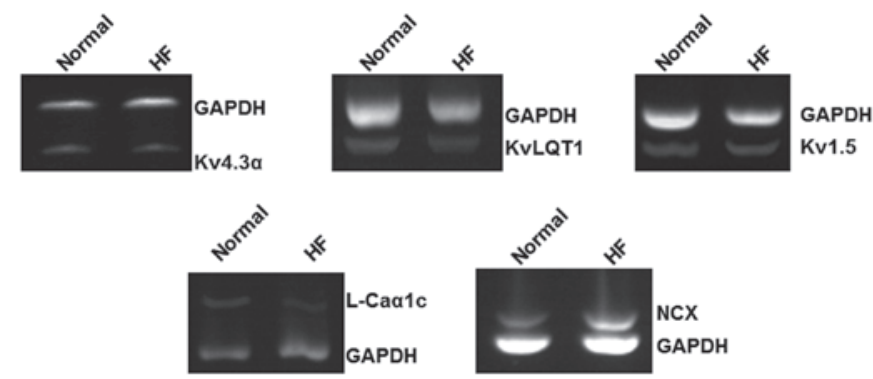

Figure 1. RT-PCR of Kv4.3 $\alpha$, KvLQT1, Kv1.5, L-Ca $\alpha_{1 c}$, NCX and GAPDH mRNA in the normal cardiac function and HF groups. Open-chest cardiac surgery was performed and 50-100 mg of right atrial appendages were collected rapidly with sterilized Eppendorf tubes. The sample was frozen at $-80^{\circ} \mathrm{C}$ immediately after the addition of $0.5 \mathrm{ml}$ TRIzol. The total RNA was extracted using the TRIzol method. Total RNA was reverse transcribed in a final volume of $10 \mu \mathrm{l}$. The amplified products were separated in $1.5 \%$ agarose gels containing ethidium bromide, and examined and photographed under a UV transilluminator. RT-PCR, reverse transcription-PCR; HF, heart failure.

\section{Results}

$m R N A$ levels of genes involved in ion channel regulation of $H F$ patients. To investigate whether mRNA transcript levels of genes involved in ion channel regulation were changed, right atrial appendages were obtained from $18 \mathrm{HF}$ patients and 18 individuals with normal cardiac functions, who had undergone surgery. The total RNAs were isolated and the mRNA levels were determined by RT-PCR. The PCR products were separated on gels and the OD values of the relevant bands of interest were measured to compare with the OD of $G A P D H$ bands. The mRNA expression levels of $K v 4.3 \alpha, K v L Q T 1$, $K v 1.5, L-C a \alpha_{1 c}, N C X$ and GAPDH are shown in Fig. 1. The amplification bands of the target genes and the internal standard GAPDH gene are consistent with theoretically expected sizes.

As shown in Table II, compared with the mean value of mRNA levels in normal individuals $(0.34 \pm 0.07)$, the mRNA expression of $K v 1.5$ in the HF group $(0.30 \pm 0.05)$ was not significantly altered $(\mathrm{P}>0.05)$. The mRNA expression levels of $K v 4.3 \alpha, K v L Q T 1$ and $L-C a \alpha_{1 c}$ were significantly reduced in patients with $\mathrm{HF}(\mathrm{P}<0.01)$ in comparison with those detected in normal individuals $(0.83 \pm 0.07$ versus $0.45 \pm 0.09,0.56 \pm 0.04$ versus $0.36 \pm 0.06,0.42 \pm 0.09$ versus $0.25 \pm 0.06$, respectively). However, the mRNA expression of $N C X$ was significantly increased in HF patients $(0.31 \pm 0.07)$ compared with those detected in normal individuals $(0.19 \pm 0.05, \mathrm{P}<0.01)$. These results suggest that mRNA levels of some ion channel-related genes may be altered in HF patients.

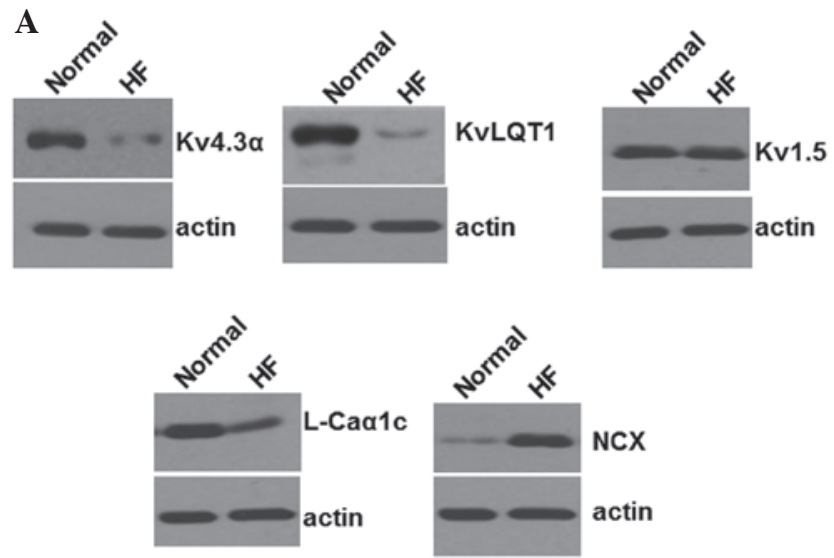

B

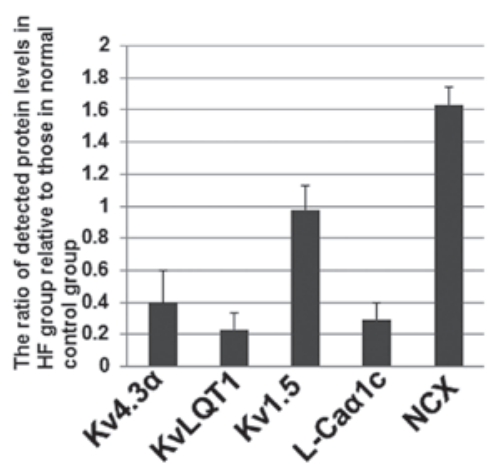

Figure 2. Western blotting of proteins encoded by the $K v 4.3 \alpha, K v L Q T 1$, $K v 1.5, L-C a \alpha_{1 c}$ and $N C X$ genes. (A) Total protein was harvested, separated by SDS/PAGE and subjected to immunoblot analyses. The primary antibodies against Kv4.3 $\alpha$, KvLQT1, Kv1.5, L-Ca $\alpha_{1 \mathrm{c}}$, NCX and actin were purchased from Santa Cruz Biotechnology, Inc. (Santa Cruz, CA, USA). Bound antibodies were detected using the ECL system (Pierce Biotechnology, Inc., Rockford, IL, USA). (B) The immunoblot experiments were repeated at least 3 times. The mean normalized OD of detected Kv4.3 $\alpha$, KvLQT1, Kv1.5, L-Ca $\alpha_{1 \mathrm{c}}$ or NCX protein bands relative to the OD of the actin band from the same individual was calculated, respectively. The mean \pm SD was calculated. OD, optical density; HF, heart failure.

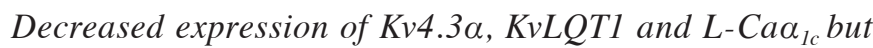
increased expression of $N C X$ in $H F$ patients. To investigate

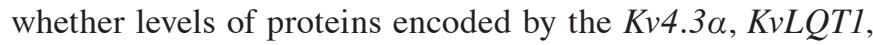
$K v 1.5, L-C a \alpha_{1 c}$ and $N C X$ genes were altered in comparison to those in normal controls, total protein was harvested from tissues, separated by $10 \%$ SDS/PAGE and then subjected to immunoblot analyses. The cellular actin protein served as a loading control. Representative blots are shown in Fig. 2A. The mean normalized OD of these protein bands relative to 
the OD of the actin band from each individual was calculated and subjected to statistical analyses. Error bars represent the mean $\pm \mathrm{SD}(\mathrm{P}<0.05$, Fig. 2B).

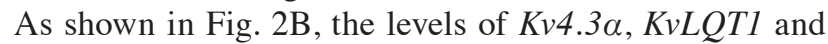
$L$ - $C a \alpha_{1 c}$ were significantly decreased to $0.41 \pm 0.21,0.23 \pm 0.11$ and $0.29 \pm 0.13$, respectively, in the HF groups, when the levels in the normal control group were artificially set as $1 . K v 1.5$ levels were not altered significantly in the HF group when compared with the normal group with a value of $0.98 \pm 0.15$. However, expression levels of NCX were significantly increased in HF patients $(1.63 \pm 0.12)$ when compared with the normal group (Fig. 2B). These results suggest that the altered expression of Kv4.3 $\alpha$, KvLQT1, L-Ca $\alpha_{1 \mathrm{c}}$ and NCX involved in ion channels of atrial myocytes may be correlated with risk of $\mathrm{AF}$ in patients with HF.

\section{Discussion}

In this study, we have identified possible alterations in atrial cellular ion currents and molecular mechanisms involved in HF. The underlying mechanisms predisposing HF patients to AF were also investigated. We demonstrated that when compared with the normal cardiac function group, the mRNA expression levels of $\mathrm{Kv} 4.3 \alpha, \mathrm{KvLQT1}$ and L-Ca $\alpha_{1 \mathrm{c}}$ were all significantly reduced in patients with HF. The mRNA expression levels of Kv1.5 were not evidently altered, while mRNA expression of NCX increased significantly. Thus, the changes of gene expression were in accordance with the ion current alterations observed in the aforementioned studies (10-12).

$\mathrm{I}_{\mathrm{tol}}$ has been identified as the major component of phase 1 action potentials. Kääb et al (13) studied dog models with pacing-induced HF, and discovered that the pharmacological reduction of Ito by 4-aminopyridine in the control group decreased the notch amplitude and prolonged the action potential duration (APD), suggesting that downregulation of $\mathrm{I}_{\mathrm{tol}}$ in pacing-induced $\mathrm{HF}$ is, at least partially, responsible for prolongation of the action potential. Several compensatory mechanisms have been proposed. It is particularly well known that neurohormones are activated to promote long-term deterioration of cardiac function and structure. Activation of the renin-angiotensin-aldosterone system leads to an increase in the circulation of AngII, and furthermore a decrease in the $\mathrm{I}_{\mathrm{tol}}(14)$, which results in a significant difference in distribution and an increase in repolarization dispersion, and finally induce cardiac arrhythmia after combination with the receptor.

$\mathrm{I}_{\mathrm{Ks}}$ is the major source for the repolarization of the action potential (15). Previous evidence indicated that $\mathrm{I}_{\mathrm{ks}}$ and the mRNA expression levels of KvLQT1 are reduced in patients with HF (16). The downregulation of $\mathrm{I}_{\mathrm{Ks}}$ and $\mathrm{I}_{\mathrm{tol}}$ contribute to the prolongation of APD, which contributes to the genesis of early after depolarization (EAD) and delayed after depolarization (DAD) as well as the physiological heterogeneity of cardiac myocytes (17).

In addition, altered activity of NCX may also be strongly correlated with the genesis of AF. The increased inward $\mathrm{I}_{\mathrm{NCX}}$ in the plateau phase is important to the production of EAD. By contrast, the increased activity of NCX during the diastolic spontaneous SR $\mathrm{Ca}^{2+}$ release period may lead to a greater depolarization current and greatly increase DAD and the propensity for triggered arrhythmias in HF patients (18-20).
DAD may induce triggered activity and subsequently promote inducibility of sustained atrial tachycardia (21). The neuroendocrine system was activated and the heart rate was increased with $\mathrm{HF}$, leading to the upregulation of inward $\mathrm{I}_{\mathrm{Ca} 2+}$ and intracellular $\mathrm{Ca}^{2+}$ overload, which provides feedback inhibition of $\mathrm{L}_{-} \mathrm{Ca}^{2+}$ channels, a decrease in the inward movement of $\mathrm{Ca}^{2+}$ and a shortened action potential plateau. The overload of extracellular $\mathrm{Ca}^{2+}$ may further influence the $\mathrm{K}^{+}$channel and promote the electrical instability of cardiac cells, which could induce arrhythmia and trigger activity.

In conclusion, alterations in the gene expression of ion channels may provide the molecular basis of altered atrial cellular ion currents in patients with $\mathrm{HF}$, and furthermore, may initiate atrial arrhythmia, particularly AF, by either trigger or re-entry activity. HF-induced atrial ionic remodeling may be important in the formation of AF substrate and contribute to the potential mechanisms of $\mathrm{AF}$ in $\mathrm{HF}$.

\section{Acknowledgements}

This study was supported by the Shandong Provincial Health Department funded project (Grant No. HC119).

\section{References}

1. Grönefeld GC and Hohnloser SH: Heart failure complicated by atrial fibrillation: mechanistic, prognostic, and therapeutic implications. J Cardiovasc Pharmacol Ther 8: 107-113, 2003.

2. Franz MR, Karasik PL, Li C, Moubarak J and Chavez M: Electrical remodeling of the human atrium: similar effects in patients with chronic atrial fibrillation and atrial flutter. J Am Coll Cardiol 30: 1785-1792, 1997.

3. Pandozi C, Bianconi L, Villani M, et al: Electrophysiological characteristics of the human atria after cardioversion of persistent atrial fibrillation. Circulation 98: 2860-2865, 1998.

4. Yue L, Melnyk P, Gaspo R, Wang Z and Nattel S: Molecular mechanisms underlying ionic remodeling in a dog model of atrial fibrillation. Circ Res 84: 776-784, 1999.

5. Van Wagoner DR, Pond AL, Lamorgese M, Rossie SS, McCarthy PM and Nerbonne JM: Atrial L-type Ca2+ currents and human atrial fibrillation. Circ Res 84: 428-436, 1999.

6. Krogh-Madsen T, Abbott GW and Christini DJ: Effects of electrical and structural remodeling on atrial fibrillation maintenance: a simulation study. PLoS Comput Biol 8: e1002390, 2012.

7. Hunter RJ, Liu Y, Lu Y, Wang W and Schilling RJ: Left atrial wall stress distribution and its relationship to electrophysiologic remodeling in persistent atrial fibrillation. Circ Arrhythm Electrophysiol 5: 351-630, 2012.

8. Zhang Y, Dong D and Yang B: Atrial remodeling in atrial fibrillation and association between microRNA network and atrial fibrillation. Sci China Life Sci 54: 1097-1102, 2011.

9. Pang H, Ronderos R, Pérez-Riera AR, Femenía F and Baranchuk A: Reverse atrial electrical remodeling: a systematic review. Cardiol J 18: 625-631, 2011.

10. Li D, Melnyk P, Feng J, Wang Z, Petrecca K, Shrier A and Nattel S: Effects of experimental heart failure on atrial cellular and ionic electrophysiology. Circulation 101: 2631-2638, 2000.

11. Cha TJ, Ehrlich JR, Zhang L, Shi YF, Tardif JC, Leung TK and Nattel S: Dissociation between ionic remodeling and ability to sustain atrial fibrillation during recovery from experimental congestive heart failure. Circulation 109: 412-418, 2004.

12. Cha TJ, Ehrlich JR, Zhang L and Nattel S: Atrial ionic remodeling induced by atrial tachycardia in the presence of congestive heart failure. Circulation 110: 1520-1526, 2004.

13. Kääb S, Nuss HB, Chiamvimonvat $\mathrm{N}$, et al: Ionic mechanism of action potential prolongation in ventricular myocytes from dogs with pacing-induced heart failure. Circ Res 78: 262-273, 1996.

14. Mankad S, d'Amato TA, Reichek N, et al: Combined angiotensin II receptor antagonism and angiotensin-converting enzyme inhibition further attenuates postinfarction left ventricular remodeling. Circulation 103: 2845-2850, 2001. 
15. Charpentier F, Mérot J, Loussouarn G and Baró I: Delayed rectifier $\mathrm{K}(+)$ currents and cardiac repolarization. J Mol Cell Cardiol 48: 37-44, 2010.

16. Thomas D, Wimmer AB, Karle CA, et al: Dominant-negative I(Ks) suppression by KCNQ1-deltaF339 potassium channels linked to Romano-Ward syndrome. Cardiovasc Res 67: 487-497, 2005.

17. Xu X, Rials SJ, Wu Y, et al: Left ventricular hypertrophy decreases slowly but not rapidly activating delayed rectifier potassium currents of epicardial and endocardial myocytes in rabbits. Circulation 103: 1585-1590, 2001.

18. Pogwizd SM, Schlotthauer K, Li L, Yuan W and Bers DM Arrhythmogenesis and contractile dysfunction in heart failure: Roles of sodium-calcium exchange, inward rectifier potassium current, and residual beta-adrenergic responsiveness. Circ Res 88: 1159-1167, 2001
19. Pritchard TJ and Kranias EG: Junctin and the histidine-rich Ca2+ binding protein: potential roles in heart failure and arrhythmogenesis. J Physiol 587: 3125-3133, 2009.

20. George $\mathrm{CH}$ : Sarcoplasmic reticulum $\mathrm{Ca} 2+$ leak in heart failure: mere observation or functional relevance? Cardiovasc Res 77: 302-314, 2008.

21. Stambler BS, Fenelon G, Shepard RK, Clemo HF and Guiraudon CM: Characterization of sustained atrial tachycardia in dogs with rapid ventricular pacing-induced heart failure. J Cardiovasc Electrophysiol 14: 499-507, 2003. 